\title{
THE DISTRIBUTION OF CELLS IN PERIPHERAL BLOOD SMEARS
}

\author{
BY \\ E. DAVIDSON \\ From Groote Schuur Hospital, University of Cape Town
}

(RECEIVED FOR PUBLICATION MAY 1, 1958)

The factors influencing the distribution of cells in smears are complex. The specific gravity and the size of the cells, the surface tension, capillarity and viscosity of the fluid medium, and the driving force of smearing all play a part in distributing the cells (Schill, 1936; van den Berghe and Blitstein, 1946). Stickiness of the cells has been quoted as a possible factor (Dacie, 1956).

In a given preparation the fluid medium and the driving force are factors which are common to all the cells and the only two important known variables are the specific gravity and the size of the cells.

The object of the present study was to determine whether one of the variables played a dominant role in determining the distribution of the cells in peripheral blood smears. It is generally observed that the larger cells tend to collect at the very edge and tail of the smear, but no general principle has been formulated.

\section{Method}

Peripheral blood smears were made from four patients suffering from chronic myeloid leukaemia. Each smear was divided into blocks $2-3 \mathrm{~mm}$. square, the dividing lines running parallel to the edges of the slide. Differential counts were carried out as follows: (1) Five hundred consecutive cells were examined in each block or area. The distribution of 20,000 cells in four slides was studied. (2) The blocks were selected so that four were placed in the proximal half of the smear and four in the distal half of the smear. In each half two blocks were placed in the central part of the smear and two blocks at the edge of the smear. (3) Counts were done at the tail of the smear and at the very edge, the latter being defined as a track along the edge of the smear no greater than the diameter of an oil immersion field.

\section{Method of Analysis of the Differential Counts}

The results were analysed in two planes-namely, the centre/edge and the proximal/distal plane.

The absolute cell counts for each cell type in all the centre blocks of all the smears were totalled. The edge, proximal, and distal blocks were treated in the same manner. In the case of the very edge and tail counts the results were multiplied by 4 to standardize the total counts for each region to 8,000 cells.

Eosinophils are not included in the analysis as the detailed differential counts were numerically inadequate.

\section{Results}

The differential counts are set out in Table I with the ratios in Table II and Fig. 1 .

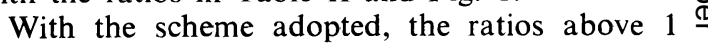
indicate the tendency of the cell to occur maxis

TABLE I

DIFFERENTIAL COUNTS

\begin{tabular}{|c|c|c|c|c|c|c|c|c|}
\hline \multirow[b]{2}{*}{$\begin{array}{c}\text { All } \\
\text { Patients } \\
\text { Absolute } \\
\text { Figures }\end{array}$} & \multirow[b]{2}{*}{ 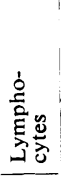 } & \multirow[b]{2}{*}{ 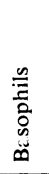 } & \multirow[b]{2}{*}{$\begin{array}{l}\frac{n}{\overline{0}} \\
\frac{\overrightarrow{0}}{m}\end{array}$} & \multicolumn{4}{|c|}{ Neutrophil } & \multirow[b]{2}{*}{ 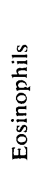 } \\
\hline & & & & 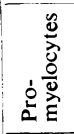 & $\begin{array}{l}\frac{\tilde{s}}{2} \\
\frac{\delta}{0} \\
\frac{0}{0} \\
\sum\end{array}$ & 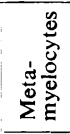 & 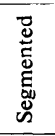 & \\
\hline $\begin{array}{l}\text { Centre blocks. . } \\
\text { Edge blocks .. } \\
\text { Very edge } \\
\text { Proximal blocks } \\
\text { Distal blocks .. } \\
\text { Tail .. }\end{array}$ & $\begin{array}{r}255 \\
182 \\
12 \\
263 \\
174 \\
12\end{array}$ & $\begin{array}{r}219 \\
194 \\
19 \\
222 \\
166 \\
16\end{array}$ & $\begin{array}{r}1,207 \\
1,295 \\
343 \\
1,269 \\
1,233 \\
361\end{array}$ & $\begin{array}{r}866 \\
980 \\
376 \\
859 \\
1,037 \\
413\end{array}$ & $\begin{array}{l}856 \\
903 \\
240 \\
868 \\
941 \\
239\end{array}$ & $\begin{array}{r}3,394 \\
3,246 \\
748 \\
3,335 \\
3,305 \\
703\end{array}$ & $\begin{array}{l}891 \\
882 \\
189 \\
922 \\
851 \\
162\end{array}$ & $\begin{array}{l}154 \\
152 \\
184 \\
139 \\
177 \\
25\end{array}$ \\
\hline
\end{tabular}

TABLE II

RATIOS

\begin{tabular}{|c|c|c|c|c|c|c|c|}
\hline Ratio & 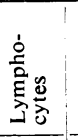 & 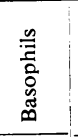 & 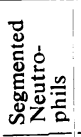 & 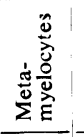 & 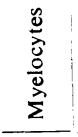 & 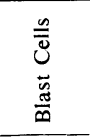 & 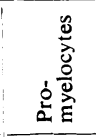 \\
\hline \multirow{6}{*}{$\begin{array}{l}\text { Centre, edge } \\
\text { Centre, very } \\
\text { edge } \\
\text { Proximal, } \\
\text { distal } \\
\text { Proximal, } \\
\text { tail } \\
\text { *Mean }(\mu) \\
\text { size of cell } \\
\text { †Specific } \\
\text { gravity... }\end{array}$} & 1.40 & 1.13 & 1.01 & 1.05 & 0.95 & 0.93 & 0.88 \\
\hline & $5 \cdot 31$ & $2 \cdot 88$ & $1 \cdot 18$ & 1.13 & 0.89 & 0.88 & 0.58 \\
\hline & 1.51 & 1.34 & 1.08 & 1.01 & 0.92 & 1.03 & 0.83 \\
\hline & 5.50 & 3.47 & 1.42 & $1 \cdot 19$ & 0.91 & 0.88 & 0.52 \\
\hline & 6.0 & $10 \cdot 2$ & $10 \cdot 2$ & $10 \cdot 2$ & 12.9 & $13 \cdot 3$ & $16 \cdot 3$ \\
\hline & 1.063 & 1.070 & 1.080 & 1.080 & 1.070 & $<1.070$ & $<1.070$ \\
\hline
\end{tabular}


mally at the central and proximal part of the smear. Conversely, the ratios below 1 indicate the teridency of the cell to occur maximally at the edge and distal part of the smear. The amount above or below unity is also an expression of the degree to which the tendency is present.

The following pattern is present (three discordant figures) :

(1) In all cases the centre/ edge and the proximal/distal tendency is accentuated in the centre/very edge and the proxi$\mathrm{mal} /$ tail ratios respectively.

(2) The lymphocytes, basophils, segmented neutrophils, and metamyelocytes tend to $\propto$ occur maximally at the central and proximal parts of the smear (ratios above 1) and the myelocytes, promyelocytes, and blast cells at the edge and distal parts of the smear (ratios below 1).

(3) The degree to which the tendency is present can be correlated directly with the mean diameter of the cell.

\section{Discussion}

The arrangement of the cells according to size in this correlation is based on the generally accepted mean diameters of the white cells in peripheral blood smears (Wintrobe, 1956; Bessis, 1956 ; Darmady and Davenport, 1954 ; Whitby and Britton, 1953 ; Albritton, 1952 ; Undritz, 1952). In the process of smearing, the concern is with the size of the living cells. There is no evidence to suggest that the relative size of the living cells differs from that seen in peripheral blood smears (Thorell, 1947 ; Kristenson, 1949). There is also no evidence to suggest that the relative size of the cells is altered in chronic myeloid leukaemia.

\section{Summary}

The factors involved in the process of smearing are complex, but size alone is the dominant factor determining the distribution of cells in peripheral blood smears. 